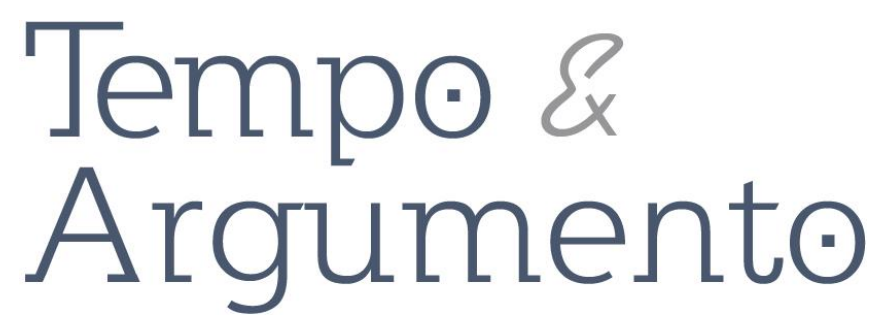

\title{
Wasted Spaces, Resisting People: the politics of waste in Naples, Italy
}

\begin{abstract}
This article explores how the waste crisis in Naples, which has been occurring since the 1990s, has stimulated the political creativeness of local activists who have started to experiment new ways for participation and community building. In particular, we investigate how environmental justice struggles have evolved in commoning processes (that is, in the creation of participatory institutions and in the defense of commons) by studying the social mobilization in Chiaiano, a neighborhood at the northern periphery of Naples (Italy). Using oral history interviews, documents produced by grassroots organizations, mass media reports, and our participants' observation notes, we have analyzed the evolution of the mobilization in Chiaiano, the connections between environmental concerns and commoning, and the results in terms of social experimentation.
\end{abstract}

Keywords: Environmental Justice. Commoning. Participatory Democracy. Waste. Naples (Italy).

\author{
Marco Armiero \\ PhD in Economic History, Università degli \\ Studi di Bari. Director of the KTH \\ Environmental Humanities Laboratory in \\ Stockholm. \\ SWEDEN \\ armiero@kth.se \\ orcid.org/0000-0002-6063-9477

\section{Leandro Sgueglia} \\ PhD in Gender Studies by the Università \\ Federico II di Napoli. Professor of modern \\ and contemporary history at the Università \\ degli Studi di Napoli 'Federico II'. \\ ITALY \\ leandro.sgueglia@gmail.com
}

\section{To cite this article:}

ARMIERO, Marco; SGUEGLIA, Leandro. Wasted Spaces, Resisting People: the politics of waste in Naples, Italy. Tempo e Argumento, Florianópolis, v. 11, n. 26, p. 135 -156, jan./abr. 2019. 


\title{
Espaços desperdiçados, pessoas resistentes: a política do desperdício em Nápoles, Itália
}

\begin{abstract}
Resumo
Esse artigo explora como a crise do desperdício em Nápoles, que tem ocorrido desde os anos 1990, tem estimulado a criatividade política de ativistas locais que começaram a experimentar novas maneiras de participação e construção comunais. Particularmente, investigamos como problemas da justiça ambiental têm evoluído em processos comunais (isto é, na criação de instituições participativas e na defesa de bens comuns) através do estudo da mobilização social em Chiaiano, uma vizinhança na periferia nortista de Nápoles (Itália). Utilizando entrevistas orais, documentos produzidos por organizações comunocêntricas, relatórios advindos de mídias de massa e das observações de nossos participantes, a evolução da mobilização em Chiaiano e as conexões entre preocupações ambientais e comunais, os resultados em termos de experimentação social foram analisados.
\end{abstract}

Palavras-chave: Justiça ambiental. Comuna. Democracia participativa. Gasto. Nápoles (Itália).

\section{Introduction}

In the last few years, Naples and its region, Campania, have become global icons of the urban ecological disaster. Everywhere, newspapers and televisions have shown the images of the city almost flooded by garbage. The hidden side of this disaster-that is, the illegal toxic contamination and the social mobilization of people against environmental injustice did not have the same media exposure. In this chapter, we will show the case of a resisting community in the north periphery of Naples and how their mobilization evolved from the opposition to a landfill to the creation of new commons, both as collective institutions-which will be called "social garrison"-and common space-the cooperative farm Selva Lacandona. 
In fact, the history of the waste crisis in Campania has produced ecological disasters but also political horrors, especially for what concerns the state of democracy and participation. The Italian national governments have approached the waste problem creating a state of emergency in the region, depriving local authorities of their own functions and centralizing the decisions about this matter. This expertification and centralization of decisions have reinforced the distance between institutions and people but, at the same time, opened a way for women and men, usually excluded from political decision-making, to experiment in direct action. As a result, numerous grassroots movements have blossomed. Activists describe these movements as territorial to indicate the place-based character of their mobilization.

Speaking of territory as a socio-ecological hybrid, Arturo Escobar wrote:

The defense of the territory entails the defense of an intricate pattern of social relations and cultural constructions, and is understood by movement activists in this light. It also implies the creation of a new sense of belonging linked to the political construction of a collective life project and the redefinition of relations with the dominant society (ESCOBAR, 1998, p. 72).

The environmental struggles emerging from this mobilization have produced a democratic regeneration from below. They have opened new prospects for democracy, or rather a reappropriation of democracy by subaltern multitudes. In this way, the wordconcept "democracy" has returned to its original meaning, activating what has been called "commoning". According to De Angelis and Federici, commoning is the process through which social actors produce common institutions, common practices, and new common goods, while reclaiming and protecting the existing ones from enclosure and annihilation. ${ }^{1}$ What does it mean to produce a common dimension, common institutions, and commons? First of all, we believe that these three aspects should be understood from a materialistic rather than from a metaphysical perspective. A common dimension regards the organization of collective life on different levels: it is a third sphere alternative to both the private and public. The private sphere organizes the relationships

\footnotetext{
${ }^{1}$ Regarding this topic, we suggest reading the studies by DE ANGELIS, Massimo. Reflections on alternatives, commons and communities. The Commoner, n. 6, p. 1-14, 2003 and FEDERICI, Silvia. Revolution at point zero: housework, reproduction, and feminist struggle. Oakland, CA: PM Press, 2012.
} 
between individuals on the principle of private property. The public one organizes them on the principle of state-ownership and state decision. The principle of common dimension questions the properties and supports the use value against trade value, it bases social relationships and economic production on cooperation and experiments with a radically horizontal democracy. In order to give concrete form to this dimension, common institutions are needed.

Commoning is the practice that active citizens have implemented in the struggles in Campania. They have defended endangered resources not as public goods but as commons. In this process, they have experimented with new common institutions, becoming a political point of reference in their communities, sometimes a sort of new institution which has challenged the existing ones.

The fulcrum of this counter-hegemonic commoning has been the presidio permanente, which we translated as "permanent social garrison".

Wherever there has been resistance against the opening of a landfill, an incinerator or an organized protest against illegal disposal of toxic waste in Campania, often the activists have created "permanent social garrisons" that put together concerned citizens, informal grassroots associations, and other kinds of militant organized groups. Certainly, permanent social garrisons are operational tools to organize the struggle, but their significance goes beyond this. The social garrison is mainly a popular assembly where participants make decisions regarding the life of the communities. Activists often define those social garrisons as an agora of the 21st century. Facing disillusionment for public institutions and traditional political parties, active people have created those new political spaces for discussion and participation. They are based on personal relations rather than on bureaucracy, on the production of a shared language and shared decisions (while enhancing any kind of difference) rather than on delegation. Finally, those grassroots experiences are based on the elaboration of social knowledge instead of on relying on individual specialized experts or intellectuals. 
As it is evident from our case study, social garrisons have often become the place where people have brought all kinds of collective problems, from those concerning public green spaces to reopening and giving new meanings to abandoned buildings. Indeed, the struggles for environmental justice have produced a commoning process, which has gone beyond the mobilizing issue of waste and toxic contamination. While expanding towards total community engagement, those movements have also acted on a broader level. Not only they have contested specific facilities or denounced particular contamination, but they have also elaborated a critique of the hegemonic model of development and mainstream democratic procedures. In other words, those movements have not demanded a better management of waste and territories from government and corporations, but rather have fought to decide directly on their communities. In doing so, they have framed communities and territories as a whole and interconnected network of air, water, soil, social relations, culture, economies, health, and landscape, which cannot be enclosed into the property scheme, either the private or the public one.

In this chapter, we explore how environmental justice struggles have evolved in commoning processes through the case study of the social garrison in Chiaiano, a neighborhood at the northern periphery of Naples (Figure 1). Chiaiano is a rural/urban area where, in 2008, the Committee for Waste Emergency (an ad hoc agency that manages waste in the Campania region, created by the national government in 1994) decided to open a massive landfill in the middle of a peri-urban natural park. Using oral history interviews, ${ }^{2}$ documents produced by grassroots organizations, mass media reports, and our participants' observation notes, we have analyzed the evolution of the mobilization in Chiaiano, the connections between environmental concerns and commoning, and the results in terms of social experimentation. But, before diving into the Chiaiano landfill and struggles, it is necessary to offer a brief introduction to the Campania waste emergency.

\footnotetext{
${ }^{2}$ The interviews used in this chapter are all available online at http://metrostorie.altervista.org/.
} 


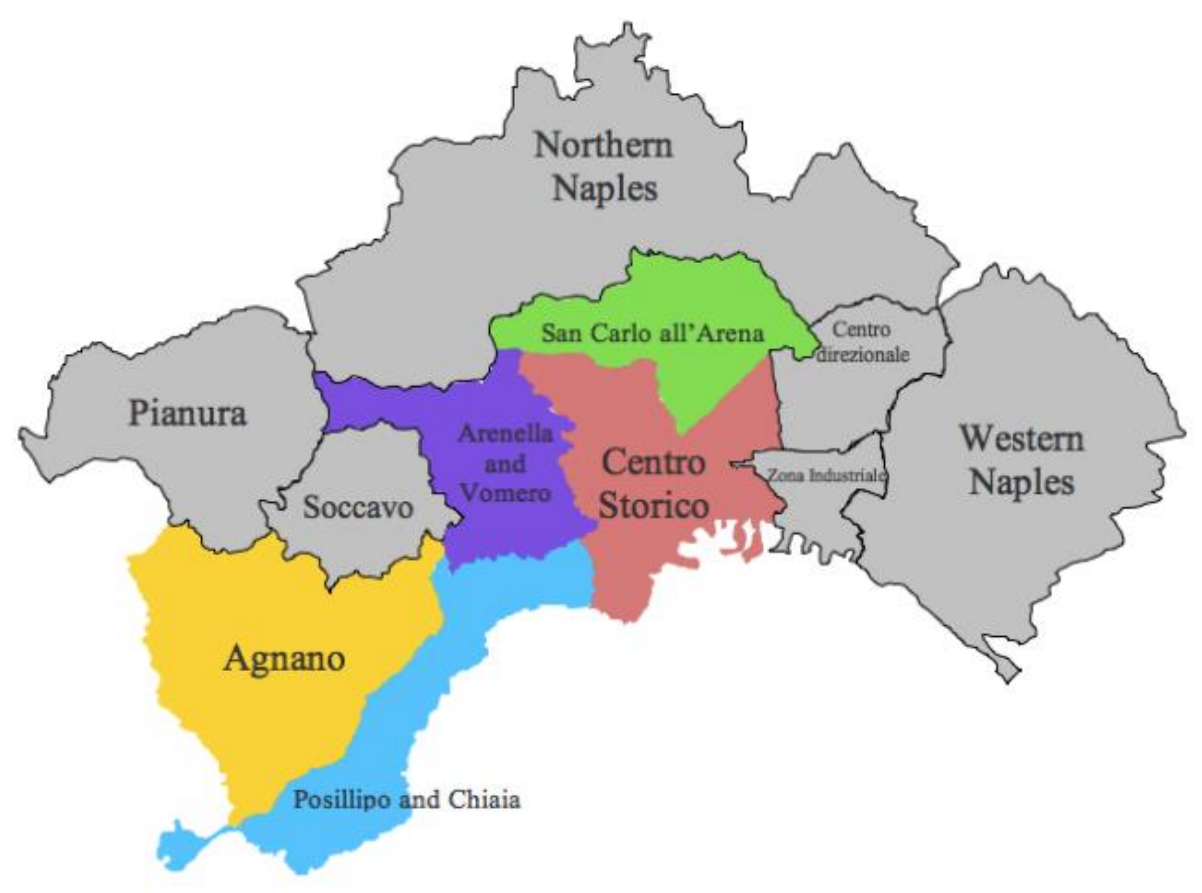

\section{South Waste Story}

The history of the so-called waste crisis in Campania dates back to 1994, when the government declared a state of emergency in waste management, creating the abovementioned special agency (CWE), with the aim of solving the problem thanks to its special powers and economic resources. ${ }^{3}$ This choice stressed the exceptionality of the waste crisis, shifting power from local authorities to this agency, derogating the ordinary regulations concerning landfill and incinerators, choosing to place those facilities in sites which were already contaminated.

That year is indeed an appropriate date, as it marks the beginning of the emergency regime, which, in our opinion, is a hallmark determining much of the story to

\footnotetext{
3 On the waste crisis in Campania, see: D'ALISA Giacomo et al. Conflict in Campania: waste emergency or crisis of democracy. Ecological economics, v.70, n 2, p. 239-249, Dec. 2010; ARMIERO, Marco; D'ALISA Giacomo. Rights of resistance: the garbage struggles for environmental justice in Campania, Italy. Capitalism Nature Socialism, v. 23, n. 4, p. 52-68, 2012; ARMIERO, Marco; D'ALISA Giacomo. Voices, clues, numbers: roaming among waste in Campania. Capitalism Nature Socialism, v. 24, n.4, p. 7-16, 2013; ARMIERO, Marco. Garbage under the volcano: the waste crisis in Campania and the struggles for environmental justice. In: A HISTORY of environmentalism: local struggles, global histories. London: Bloomsbury, 2014.
} 
come. The philosophy and practice of emergency would merit a specific study, since it has two implications: the state of emergency has implied the reduction of the space of democracy and discussion in favor of rapid and authoritarian decisions, as well as authorized the overcoming of ordinary rules and procedures regarding both the environment and the procurements.

Nonetheless, 1994 is, as every date in history, only the conventional starting point of the waste crisis in Campania. Instead, it could be dated at least from the 1980s, when the regional mafia, called Camorra, in collaboration with entrepreneurs from the North and corrupted politicians, transformed the Campania region in the "dustbin of Italy". Criminal organizations were able to offer to dispose of all kinds of toxic waste for less than a tenth of what was charged in the legal market. However, the 1994 crisis did not start with the issue of illegal toxic waste trafficking; it was mainly a crisis concerning the disposal of urban garbage, and government bodies and public opinion stayed focused on that for many years, until grassroots mobilization was able to shift the attention to the toxic contamination. ${ }^{4}$ As activists and prosecutors have argued, the disorder in the disposal of urban garbage has been instrumental in the introduction of toxic waste in Campania. Since the 1990s, the authorities had known that the state of the landfills in the region was extremely precarious; according to an investigation, only 21 of the 124 active landfills in the region between 1992 and 1994 were in accordance with the regulations. Thereby, it should not have been a surprise when, in 1994, the judiciary imposed the foreclosure of several landfills, some having been exhausted, some illegally or improperly managed. From 1994 onwards, the special agency for the management of waste in Campania has worked frantically to find places garbage disposal while waiting for the construction of an incinerator which, in the CWE's plans, was intended to solve the excess garbage problem. By force of the emergency regime, several waste facilities have been opened without complying with the norms and technical infrastructures required for their correct functioning. This was the case, for instance, at the temporary storage site of Ferrandelle, a rural area in the province of Caserta, which was used in 2008 by the

\footnotetext{
${ }^{4}$ Regarding this topic, we suggest: CAPONE Nicola; CUCCURULLO Antonella; MICILLO Flora. Allarme rifiuti tossici: cronaca di un disastro annunciato. Napoli: Assise Palazzo Marigliano, 2006. Available at http://www.napoliassise.it/rifiuti\%2otossici.pdf. Accessed: 8 July 2015.
} 
Berlusconi government to clean Naples from the trash (D'ALISA-ARMIERO, 2013). After many complaints by activists, including a petition to the European Parliament, the judiciary seized the landfill and commenced a trial against several officers responsible for that waste facility. In 2016, the judges have condemned the Ministry of the Environment to indemnify the municipality recognizing that the Ferrandelle landfill did not comply with safety regulations. ${ }^{5}$ Also, in the case of the landfill in Chiaiano, the prosecutors have found that the dump was not working properly and showed possible risks to people and to the environment.

Even the construction of the incinerator, that is, the fulcrum of the authorities' entire exit-strategy for the waste crisis, is marked by a certain degree of disregard for regulations. An officer working for the Ministry of the Environment declared to the Parliamentary special committee inquiring into the issue of waste and contamination that his office did not perform a proper environmental impact assessment for the Campania incinerator, since it was clear that the decision had already been made. ${ }^{6}$ Actually, in the case of the incinerator, according to Paolo Rabitti, a consultant of the prosecutors in the trial against the CWE and the corporation, many exceptions to the norm were made in other to facilitate the corporation. The most significant of them was the permission to store the Refused-Derived Fuel (RDF), that is, fuel produced with solid waste, better known in Campania by the name of "ecoballe", pending the construction of the incinerator where those ecoballe would have been burnt. The explanation for this lies in the special financial support - the so called CIP6 —, which the Italian government had granted to the companies producing energy from the incineration of waste. According to this norm, the incineration of garbage has been assimilated into the production of energy from renewable sources, an interpretation which has been condemned by the European Court in 2008. In the legal framework of the CIP6, it is extremely profitable for the corporation to accumulate RDF, which is the equivalent of accumulating profit; according

\footnotetext{
${ }^{5}$ The text of this verdict is available online at http://www.casertace.net/wpontent/uploads/2016/05/sentenza-ferrandele.docx (access May 2016).

${ }^{6}$ On the February 8, 2005 meeting of the Parliamentary Committee of Waste Cycle (PCWC), Dr. Agricola, from the Ministry of the Environment, has significantly stated: "In this case [for the incinerator in Acerra], we are not doing a classical environmental impact assessment. Instead, we are intervening in a process in which there is a general necessity, which has led to some decisions and which, for us, is a starting point." (PCWC 1998:doc. XXXIII/17:14).
} 
to some estimates, the value of the ecoballe amassed in Campania amounts to one billion Euros. $^{7}$ The production and storage of millions of ecoballe demonstrates clearly that the waste crisis in Campania is a case of the accumulation through contamination proposed by Joan Martinez Alier (2012) and well explained by Federico Demaria and Giacomo D'Alisa (2013): the capitalistic system expands itself, contaminating the environment and the body of subaltern people.

On December 31, 2009, the state of emergency was declared closed and the local institutions were again in charge of the waste management in the region; nevertheless, the situation in Campania is still critical, especially due to the large extension of land needing reclamation because of toxic contamination. According to the Campania Agency for Environmental Protection, there are about one thousand illegal dumps, full of all kinds of toxic waste, coming from Northern Italian factories in the region. As a result, Campania has the largest number of contaminated areas in the nation, with four "Sites of National Interest" — that is, places highly contaminated and needing reclamation —, including in their territories seventy-four municipalities and an astounding number of illegal dumps.

FIGURE 2 Chronology of the waste crisis in Campania

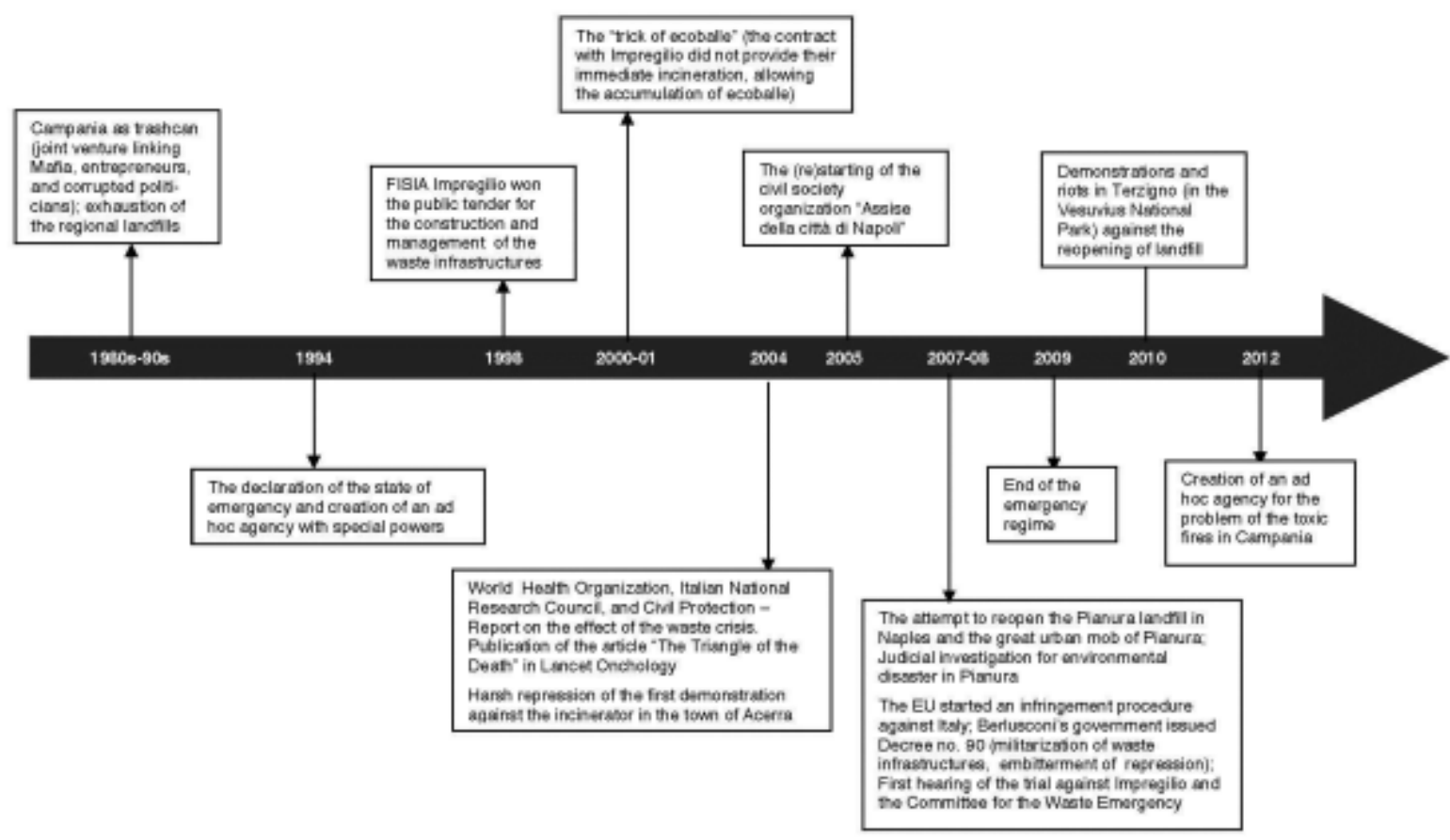

\footnotetext{
7 It is difficult to say the exact amount of "ecoballe" in Campania; they should be between 5 and 8 million.
} 


\section{The landfill and the neighborhood}

On May 23, 2008, at the so-called Titanic roundabout in Chiaiano, women and men were assembled in a picket line, controlling access routes to the quarry from that strategic position. By then, it was public knowledge that the police, with all their means, aimed to enter the quarry in order to transform the site into a gigantic landfill. This was the immediate effect of the new political climate generated by the elections, which brought Silvio Berlusconi and his right-wing coalition to power. During the electoral campaign, Mr. Berlusconi had employed the waste crisis in Naples to demonstrate the incompetence of the center-left coalition to rule the country, promising to rapidly solve the problem, if elected. Thereby, with the new government in power, those responsible for law and order definitively choose to overcome the political opposition coming from the community. This opposition was also supported by local administrations, but the national government and mainstream media described it as a problem of law and order. According to the authorities, a security emergency was compounding the ecological and health emergency caused by the waste crisis. This mainstream narrative claimed, that on the streets of Chiaiano, the Camorra had mobilized its younger affiliates to create disorder and stop the construction of the landfill in order to preserve their financial interests in the area. Apparently, Camorra had different plans for the Chiaiano quarry. According to authorities and journalists, the social mix in the Chiaiano streets was even more explosive due to the presence of activists from social centers and antagonist left who were there to foster their political agenda. ${ }^{8}$ For mainstream journalists and opinion leaders, local citizens were only a façade for Camorra and radical leftist activists, therefore, the government had to act with an iron fist. Those who have narrated this struggle from the prospective of local people talk instead of a real movement, a real multitude of women and men who have democratically chosen their own practices, rejecting any accusation of subordination to strong powers, including those of the Camorra.

\footnotetext{
8 The Centri Sociali (Social Centers) are old, abandoned buildings squatted by young activists and transformed into centers for political, cultural, and recreational activities. On this experience, see: MUDU, Pierpaolo. Resisting and challenging neoliberalism: the development of Italian social centers. Antipode, v. 36, n. 5, 2004.; Massimo Rispetto, a documentary directed by Paolo Virzì, https://www. youtube.com/watch?v=YSf4SsGwLHI (accessed on 20 August 2015). On anti-globalization movements and the environment, see: MERCHANT, Carolyn. Radical ecology: the search for a livable world. New York: Routledge, 2005.
} 
"We knew about the project of opening a landfill through a voice coming from a car with speakers which invited all the citizens to an assembly," narrated Palma, one of the local dwellers who lived through the struggles from the beginning and would later become one of the faces of the environmental movement in Naples. Serena, her daughter, who was also involved in the mobilization, added:

So, we went to the first assembly where people started to get organized. We were trying to build a collectivity which could resist that project [the opening of the landfill], but, at that time, we did not even know each other (FIORETTI; KAISER; SGUEGLLIA, 2014).

The protest began slowly as the rumors became more and more concrete. Not all were ready to fight. "Some among us," Serena said, "thought that the State's decision was irrevocable, that nobody could do anything to change it. However, others believed that it was possible to do something, and they wanted to be involved."

At the time when the landfill was planned, the center-left government of Mr. Prodi was still in power. The city of Naples and the Campania region were also ruled by a center-left coalition, although they rarely commented on it, since waste management was entrusted to the CWE. At that time, the chair of that agency was the former chief of police, Mr. Gianni de Gennaro. He was one of the main supporters of the project to open the landfill in Chiaiano, although most of the Neapolitan city council opposed that option. On April 30, the Prime Minister Romano Prodi signed the ordinance which mandated the CWE to open the landfill in Chiaiano. With this formal passage, the protest in the territory gained strength. The local dwellers understood that they had to be on the frontline, placing their own bodies in the struggles to protect their community. Learning from the practices employed by other resisting communities, especially those in the Susa Valley, ${ }^{9}$ the Chiaiano activists built barricades on the streets, leading to the quarry, and organized themselves into the permanent social garrison located at the entrance of the area where the landfill was planned. At the beginning of May, when the streets of Naples and

\footnotetext{
9 The movement against the construction of the High-Speed Train rail system (in Italian, TAV) in the Susa Valley has produced one of the most significant environmental struggles in the country. Many grassroots organizations referred to this experience as an example of long-lasting mobilization. On the Susa valley case, see: DELLA PORTA, Donatella; DIANI Mario. Voices of the valley, voices of the straits: how protest creates communities. Oxford-New York: Berghahn Books, 2008; ARMIERO, Marco. A rugged nation: mountains and the making of modern Italy. Cambridge, UK: White Horse press, 2011.
} 
especially of its peripheries were still flooded by waste, the government changed and De Gennaro's mandate expired. The new center-right coalition lead by Mr. Berlusconi entrusted the CWE and the solution of the waste crisis to Guido Bertolaso, the chief of the Italian Agency for Civil Protection. To signal the significance that the new government gave to the waste crisis, Mr. Berlusconi convened the first Cabinet in Naples, ruling the Decree 90-23/5/2008 (after Law 123), which designated the areas for landfills. Those areas and all the waste facilities were declared sites of strategic interest, in other words, they were assimilated to military bases and, therefore, were inaccessible to people. Demonstrations were forbidden and even the access of representatives from local authorities, generally opposing those facilities, were limited. The right-wing coalition opted for intransigence in dealing with grassroots protests. Since Mr. Berlusconi had promised, during the electoral campaign, to solve the waste crisis in Naples, the government was thereby committed to do so, by any means possible, including overcoming democracy, popular opposition, and the ecological limits of specific territories. After all, Mr. Berlusconi and his government were not clear about what they meant by solving the allegedly waste crisis of Campania. If the trash bags in the streets of Naples were the crisis and the solution was simply putting them out of sight of tourists and of the middle-upper class Neapolitans, maybe Mr. Berlusconi was indeed working in the right direction.

The news about the militarization of waste infrastructures fostered popular opposition. The barricades of May 23 were a countermove to prevent the army from taking over the quarry. That day evolved into a savage clash between the police and the demonstrators, opening the most intense period in the struggle. Several citizens and journalists pressed charges against the abuse of police officers; YouTube became a repository of videos proving the violence of the police against unarmed protesters.

The resistance continued for months with protesters experimenting with different kinds of practices, from confrontational to peaceful and passive ones. The use of roadblocks with bricolage barricades to stop the construction of the landfill were the most common practice of resistance. Activists also tried to expand the space of their actions, bringing the protests to sites of decision-making, such as the offices of the 
regional agency for the protection of the environment or the headquarters of the regional government. At other times, activists aimed to make the protest visible beyond the limits of their community, attempting to reach parts of the city which were not directly affected by the problem. Palma tells of the day when a group of people from Chiaiano crowed into the subway and moved to a middle-upper class neighborhood in the city to hold a spontaneous parade. Besides the usual tools of resistance and protest, the grassroots groups in Chiaiano experimented with new forms of civil disobedience. One was the so-called slow-walking, that is, a continuous and organized cross-walking on the main street of the neighborhood with the purpose of blocking traffic without committing a felony or holding a demonstration. There were symbolic funerals to represent the death the entire community. Other demonstrations acquired a symbolic value, as, for instance, the decision to hold the First of May parade in Chiaiano in 2010, with delegations of resisting communities from the entire country. In spite of popular opposition, the quarry was militarized (July 10, 2008) and the landfill opened (July 10, 2009). Nonetheless, the mobilization in Chiaiano did not stop.

Surely May 23 has represented a shifting moment in the struggle. Having experienced the heavy repression of the police, the mobilized community started to develop a political perspective beyond resistance. ${ }^{10}$ Crucial in this respect were the occasions of study and reflection occurring through public debates and the socialization of information. The creation of the website ChiaianoNoDiscarica was instrumental in the circulation of documents and in the collective edification of an "expert community". ${ }^{11}$

In the struggle against the landfill—which immediately became a struggle for an alternative vision of production, reproduction, and consumption-, a new political subjectivity was forged, increasingly assuming the dimension of a broader movement for environmental and social alternatives. The relocation of social garrison from the entrance

\footnotetext{
${ }^{10} \mathrm{~A}$ dramatic account of the clashes at the Titanic roundabout is in the autobiographical account by MUSTO, Teresa. Radici. In: ARMIERO, Marco. Teresa e le altre: storie di donne nella Terra dei Fuochi. Milano: Jaca Book, 2014.

11 On expert community, see: D'ALISA, Giacomo; KALLIS, Giorgos. Post normal science. In: D'ALISA, Giacomo; DEMARIA, Federico; KALLIS, Giorgos. Degrowth: a vocabulary for a new era. New York: Routledge, 2015, p. 185-188.
} 
to the quarry to a more central area in the neighborhood facilitated the transition from an ad hoc mobilization against a landfill to a social movement with a broader political agenda. It was at this new location, which was precisely where the clash with the police had occurred, that the informal gathering of active citizens became a more structured experience, the presidio, with physical headquarters made of sheet metal. In Italian, the word "presidio" evokes a military facility; it can be translated literally in English as garrison and it implies the control of the army over a territory. As the government increasingly militarized the territory to deal with the popular opposition, the activists chose to counterpose an alternative garrison, which also aimed to control their territory. It was a "social garrison" because it provided a space of sociality for a neighborhood that was deprived of any kind of collective dynamics. Serena narrated how the presidio made a community out of people who did not appear to have anything in common. She recollected her surprise in seeing old women sitting shoulder to shoulder with young people smoking joints.

The usual borders which designated the pre-existing identities seemed to be clearly collapsed. The social garrison was-and still is-the political laboratory where activists organized the conflict and their self-formation. In those spaces, militant scientists and activists co-produce knowledge about the risks represented by the landfill, other solutions for the management of urban waste, and broader ideas for a more sustainable society. Recollecting a meeting with Stefano Montanari, an expert on micro particles, Palma showed how the presidio generated knowledge on the risks of incinerators and informed the activists about different ways of managing waste. Serena defined the social garrison as a people's university, where activists could meet researchers regardless of the usual power structures haunting the official academic space. While being a space for co-production of knowledge, the presidio also offered the possibility of building a broader coalition with other subjects struggling to defend their rights, such as instance workers, migrants, and unemployed people.

The $1^{\text {st }}$ of May demonstration was an experiment in this coalition, gathering in Chiaiano not only other environmentalist grassroots organizations, but also people engaged in different kinds of struggles, such as the workers from the Fiat factory in 
Pomigliano, the committees against water privatization, and the antiracist network. Building on this coalition, the local struggle arrived to express a critique of the mainstream meaning of development while searching for social and environmental justice. Also, in this case, Serena's words can be useful to understand how this evolution of the movement was experienced:

We have developed a list of principles that apparently does not connect directly with our specific struggle but, instead, has so much in common. We have favored antiracism as a fundamental value, also because we, as inhabitants of Naples and the South, have always been victims of racism from the rest of the country. We have been accused of being unable to manage our waste properly due to our cultural inferiority, while the industrialists from the North have targeted our lands as the ultimate toxic dump precisely judging us inferior. For this reason, we felt supportive to the fights of others who also suffer social injustices (FIORETTI; KAISER; SGUEGLIA, 2014).

Nonetheless, the main function of the Chiaiano social garrison was to develop proposals and strategies both for the struggle and the ruling of the community. Sometimes, even the local institutions, at least at the community level, had to accept the decisions of this new agora due to its political prestige. The credibility of the presidio grew in parallel to the disrepute of the State and its institutions. It became unacceptable that the State, which had first abandoned the community for decades, would then impose military control on the territory, disregarding or, more accurately, repressing popular opposition.

Between December 2010 and March 2011, a series of investigations uncovered the connections linking some companies working on the landfill and Camorra. According to the Italian laws, those companies were banned from public contracts. During the investigations, the prosecutors also discovered that the landfill was not constructed properly, leaving people and the environment at risk. The findings of the judiciary reinforced the activists' detachment from the state; while accusing active citizens of collaborating with Camorra, the authorities had offered their land to enterprises actually connected with Camorra without ensuring the safety of people and of the environment. Framing their territories and resources as commons, the activists claimed the need for self-government as the only strategy to protect them. Between the summer and fall of 
2011, the mobilization against the landfill gained new momentum. Activists denounced the infiltration of Camorra in the management of the landfill, the terrible smell infesting the entire area, and the malfunctioning of the infrastructures reputed to protect the environment. At that time, slugs had penetrated into the soil, producing a geyser in July 2011.

The energy of social mobilization in Chiaiano expanded to the neighborhood town of Mugnano, where a grassroots association was started, joining the struggle against the landfill, but also developing its own political agenda. In the end, the struggle paid off and, in November 2011, the landfill was closed. A cathartic party was immediately held at the social garrison in Chiaiano, but as much as it marked the end of one struggle, it heralded the beginning of a new season of social mobilization. First of all, the activists from Chiaiano enlarged the main constituency of their political agenda, shifting from waste to commons. They built a coalition with other grassroots organizations from the Northern periphery of Naples; they called this coalition Rete Commons (Commons Network) and it soon became an incubator for other grassroots experiences in the entire region and even on a national scale. Furthermore, the making of the Rete Commons was also an opportunity for self-training, especially for the activists from the local social center Insurgencia, which learned through experimentation the complicated art of coalition building. The Rete Commons articulated its activism in line with the struggles for the right to the city. In reclaiming abandoned spaces, often closed for decades and decaying, those activists actually reclaimed the right to have common spaces where the social life of the community could be nurtured beyond the commodification of any interstice of the city. In Mugnano, Rete Commons reopened an abandoned urban park, renaming it Miriam Makeba Park after the well-known African singer who had died while performing at an anti-racist concert in Campania. The park became a node for social and recreational activities in the entire Northern outskirts of Naples. Starting from this experience, a group of active citizens also started a self-organized purchase cooperative, showing, again, the massive impact which the struggles for environmental justice had on this community. Buying things-primarily food-in common meant addressing both the economic crisis as well as the ecological one, since these kinds of initiatives aim to 
support local producers. The connection linking environmental activism, the reclaiming of commons, and the production of food has become stronger since 2010, when Insurgencia, the main and most organized player in the Rete Commons and in the Chiaiano mobilization, occupied fifteen hectares of arable land once owned by a Camorra family and for years seized by the judiciary power. That land, more or less on the edge of the massive quarry which had been transformed into a landfill, had stayed abandoned for years when the activists decided to trespass. Together with an anti-Camorra association, the Chiaiano activists have created a cooperative which, after some legal disputes, has been able to have officially gained control of the land. Currently, the Selva Lacandonathis is the informal name the activists have given to the area, referring to a region in Chiapas and linking this experience to the Zapatistas' autonomy movement-is both an agricultural cooperative and a social space for training and common activities. Its location, close to the landfill, offers the opportunity to monitor the contamination of soil and water, which, by the way, is still clean. The commons approach is still crucial in the management of the Selva Lacandona, where many inhabitants of the area have started collective vegetable gardens, while the cooperative has invested in the production of wine, which has been placed on the market with the appealing and explicit label of "AntiCamorra Wine". In the summer, youths from the entire nation gather in the Selva Lacandona to work together on the land, but also to debate about the Mafia, environment's stewardship, and social justice.

It was from the Rete Commons experience that another, much broader coalition was created. In 2013, almost all the grassroots organizations from Campania joined together into the Stop Biocidio coalition. The making of this new umbrella coordination overlapped with a new theoretical reflection on toxic contamination in Campania. The activists decided to frame the Campania case as "biocide", meaning with this term the killing of biological and social life in their communities. In this way, activists overcame the indecision of official science-more specifically, of medical researchers-in establishing a causal nexus between health problems and contamination; without waiting for "scientific" proof, they affirm their persuasion that the ecologies of bodies and those of the environment meet in the uneasy ground of diseases and birth defects. Biocide also 
includes the contamination of social life, that is, the fact that polluted communities are deeply affected by environmental injustice beyond the measurement of toxins in the body and in the environment. The manifesto of the Stop Biocidio coalition clearly states the vision of those grassroots organizations on the crisis in Campania:

Biocide is the effect of an inhuman economy which places people and goods on the same level, that is, as means. This economic system has dried our lands and poisoned our communities. And all in the name of maximizing profits. (..) In order to exit from the ecological crisis, it is necessary to exit from the social crisis. The right to health should not be counterposed to the right to work. We must root our actions in the dignity of all people. (...) Stopping biocide means claiming welfare and housing for everyone (FIUMEINPIENA, 2013).

Connecting the social and the ecological crisis places this movement in line with the so-called subaltern environmentalism, which strives to frame environmental injustice within the larger social injustice structures oppressing marginal groups. The reference to the job blackmail is crucial for a region such as Campania, where, in the name of a few job opportunities, everything seems to be justifiable. We know that even waste facilities, such as landfills and incinerators, have been heralded as essential opportunities to bring jobs and economic improvements into disenfranchising communities. While having a strong ideological or even idealistic ethos, the Stop Biocide manifesto also proposes a series of specific and reformist steps to address the crisis in the region, as, for instance, the creation of an Independent Technical and Scientific Observatory to monitor the health of people and the environment, the elimination of public funds for incineration, and the creation of a "superfund" to clean up the already contaminated communities. On November 16, 2013 the coalition Stop Biocidio held its first demonstration, bringing almost 100,000 people to a march in the streets of Naples.

\section{Conclusion}

Twenty years ago, Bron Taylor wrote in the conclusion to the volume Ecological resistance movements that, in several experiences of radical environmentalism, a leftist culture was meeting the ecological one while discovering the natural limits of the planet (TAYLOR, 1995). Sustainability, Taylor argued, was an important ideological tool for those 
movements. In our case, sustainability is almost absent in the activists' discourses. In twenty years, that concept has been so abused that it lost almost all its transformative power. Others seem to be the buzzwords of our times. Some are talking of degrowth, as a radical alternative to the current way of producing and consuming. Rather than on the ground of the natural limits of the planet, in the Chiaiano case study, left cultures have encountered environmentalism on the terrain of justice. This is evident in the planned attempts to connect the local struggles against toxic contamination and other struggles for workers' rights and against racism. The struggles against enclosure and for the restoration of the commons were crucial twenty years ago and still are at the core of the current ecological resistance (Ivi, 342). However, this article has demonstrated that the struggle goes beyond the defense of (pre)existing commons. Transforming commons from a thing into a practice-the commoning of Federici and De Angelis-implies the possibility to create new commons, which are not only freed spaces such as the Selva Lacandona and the social garrison, but also processes, ways of envisioning and performing the community.

The point is that, in the last twenty years, the world has changed. The economic crisis, the austerity policies in Europe, and the Occupy movement have affected the languages and practices of radical environmentalists. The awareness of the increasing divergence between a few super-rich and the other $99 \%$ has helped to frame the ecological problem into the wider context of rampant social inequalities. In the Chiaiano case, it is also clear that the single-issue model, typical of environmental mobilizations, does not work at all. From the usual struggle against a landfill, those grassroots organizations have moved to the larger framework of the "right to the city" 12 movement, (re)claiming and reinventing common spaces and collective forms of decision-making. The quest for autonomy, which was already a pillar in Bron Taylor's discussion of the

\footnotetext{
12 The "right to the city" concept has been used for the first time by Henri Lefebvre in 1968 and has been reproposed recently by David Harvey. In the World Charter for the right to the city, it is defined "as the equitable usufruct of cities within the principles of sustainability, democracy, equity, and social justice. It is the collective right of the inhabitants of cities, in particular of the vulnerable and marginalized groups, that confers upon them legitimacy of action and organization, based on their uses and customs, with the objective to achieve full exercise of the right to free self-determination and an adequate standard of living." That document is available online at http://tint.org/2011/10/world-charter-for-the-right-to-the-city/ (accessed on May 2016).
} 
popular ecological resistance movements, is still an important part of their political agenda. However, in the Chiaiano case, the explicit reference to the Zapatistas designs a more coherent and overtly political option.

Indeed, the Selva Lacandona in Chiaiano is both a symbolic and a material place. It is made of dirt, vineyards, peach trees and vegetables, as well as of the narratives connecting far-away struggles against global markets and environmental injustice. The Selva lies on the verge of the gigantic landfill, which represents the impact of the State and corporations into the ecological and social body of that community. A community is being spread all around, filled with cheap housing, dilapidated roads, and shopping malls. The transformation of an old quarry into a landfill has merged with the wider transformation of a pre-existing rural neighborhood into a bedroom area with cheap housing and few services. The result has been the creation of a subaltern periphery of the metropolis, robbed of any kind of identity. In the process of struggles which redesigned belongings and identities, a new community was shaped and came to understand the value of collective action in order to defend itself. The centrality of garbage provided an opportunity to draw connections between places and bodies, economies and politics. It also showed the subalternity of that area and those people with respect to the metropolis: Chiaiano was supposed to become the dump of the city, the terminal of the flux of undesired objects precisely as it had been the collector of the flux of undesired people.

The shift from denouncing the (present and future) contamination to claiming the rights to the commons was short. Air, soil, and water are the obvious commons that a struggle over garbage can involve. More importantly, the Chiaiano case reveals that the commons are not only places or resources in need of being protected from enclosure. Using the concept elaborated by De Angelis and Federici, we have spoken of commoning, that is, of the practice of creating commons. In this sense, what we have defined social garrison is the laboratory in which commoning was formed. We argue that it is not by chance that commoning has been developed starting from the struggles for the protection of the ecologies of bodies and the environment. Precisely in the moment when neo-liberal capitalism tends to expand its dominion over every aspect of life, 
enclosing and/or contaminating it in order to accumulate profits, communities react through commoning, that is, through the liberation of internal and external spaces not just from the capital but rather from its very logic. Making space for the Selva Lacandona on the edge of a gigantic and polluting landfill is much more than simply managing a former Camorra's land. It is a revolution in the emotional and political geography of the community, one of those revolutions where people ask for bread and roses, the vineyards and the assemblies, the festivals under the shadow of the trees and new relations between the metropolis and its periphery (Figure 3). As the Italian folksinger Fabrizio De Andrè wrote in one of his songs: it is from manure that flowers are born.

\section{Referências}

ARMIERO, Marco; D'ALISA Giacomo. What happened to the trash?: political miracles and real statistics in an emergency regime. Capitalism Nature Socialism, v. 24, n. 4, p. 29-45, 2013.

DEMARIA, Federico; D'ALISA, Giacomo. Dispossession and contamination: strategies for capital accumulation in the waste market". Lo Squaderno, v. 29, p. 37-39, Sept. 2013. Available in: http://www.losquaderno.professionaldreamers.net/?cat=162. Accessed: 20 Aug 2015.

ESCOBAR, Arturo. Whose knowledge, whose nature?: biodiversity, conservation, and the political ecology of social movements. Journal of Political ecology, v.5, n.1, p. 72, 1998.

FIORETTI, Palma; KAISER, Serena; SGUEGLIA, Leandro. "Intervista", 2014. Available in: http://metrostorie.altervista.org/chiaianomarano_nodiscarica/

FIUMEINPIENA. Come fermare il biocidio in dieci punti. Piattaforma politica, 2013. Available in: http://asud.net/come-fermare-il-biocidio-in-dieci-punti-la-piattaforma-difiumeinpiena/. Accessed: 20 Aug 2015. 
MARTÍNEZ-ALIER, Joan. Environmental justice and economic degrowth: an alliance between two movements. Capitalism Nature Socialism, v. 23, n. 1, p. 51-73, 2012.

TAYLOR, Bron. Popular ecological resistance and radical environmentalism. In: TAYLOR, Bron (Ed.). Ecological resistance movements. Albany: State University New York Press, 1995. 